\title{
The Need Analysis of Handout as A Teaching Material on Mycology Course about Antagonism between Molds at Biology Department State University of Malang
}

\author{
$1^{\text {st }}$ Anugrah Aji Pariris \\ Biology Department \\ State University of Malang \\ Malang, Indonesia \\ ajipariris@gmail.com
}

\author{
$2^{\text {nd }}$ Utami Sri Hastuti \\ Biology Department \\ State University of Malang \\ Malang, Indonesia
}

\author{
$3^{\text {rd }}$ Fatchur Rohman \\ Biology Department \\ State University of Malang \\ Malang, Indonesia
}

\begin{abstract}
This study aims to observe the needs of handout as a teaching materials in the Mycology course at Biology Department, State University of Malang. The research sample were students of Biology Department at State University of Malang who has been passed for Mycology course. The qualitative data is a survey result of handout need for students was obtained by an observation questionnaire. The observation research was analyzed by descriptive quantitative. The research result shows that the students have used the practical instruction in the Mycology learning activity, but $100 \%$ respondents explain that the topic of Antagonism between Molds have not been discussed specifically yet. All respondent explain that they have not been used handouts in Mycology learning course. Such that, all respondents explain that they need a handout about this topic in Mycology course. This research result shows that it is need to develop a handout about Antagonism between Molds for Mycology course at Biology Department, State University of Malang
\end{abstract}

Keywords-Handout, Antagonism between molds, Mycology.

\section{INTRODUCTION}

The use of teaching material is an inseparable part and it's an integration of the learning method used [1]. Teaching materials include one of the dynamic elements in learning [2]. The position of teaching materials has an important role because it can help student learning [3].

On the other hand, the use of abstract learning materials can be concretized and make the learning environment unattractive to be interesting [4]. Teaching materials in the era of technological progress is needed in the learning process. The use of good teaching materials is needed in order to help the learning process effectively and efficiently [5].

Learning that has been going on in the course of mycology, especially the topic "Antagonism Molds" at Biology Department State University of Malang already using teaching materials in the form of practical instruction. However, in its use, the practical instruction has not been able to explain the topic of " Antagonism between Molds" specifically and detail so that the knowledge and understanding of the students on that topic is still not in depth.
In improving students' effectiveness in learning the topic of "Antagonism between Molds" in the subjects of Mycology, the lecturer are required to use teaching material with the contents of the material in more detail and appropriate competence in this case as the handout or student's handbook. Handout are usually created for instructional purposes [6].

Handouts make learning "portable and enduring" (easy to carry anywhere and lasting) and can reload the information students have acquired and develop tests for students [7]. This study aims to observe the needs of handout as a teaching materials in the Mycology course at Biology Department State University of Malang.

\section{METHODS}

This research conducted a Survey research type by spreading question questionnaire that has been completed with answer choice and filled directly by the respondent. The sample in this research were 15 students of 2014 class who already pass the course of Mycology in Biology Department State University of Malang.

Handout need analysis sheet contains 8 questions. Each question has two answer options except question number 5 with 4 answer choices. Data were analyzed using percentage of the answers given by the students on the need analysis sheet. Questions in questionnaire need analysis i.e.

1. Have you ever obtained the Myology course with the topic of Antagonism Between Molds?

[] Ever

[] Never

2. Are there practical activities in the topic?

[] Present

[] Absence

3. Have you ever practiced of topic "Antagonism Between Molds"?

[] Ever

[] Never

4. Are you in the practical activity already using learning material?

[] Already used

[] Not used yet 
5. What type of instructional material have you used? (Option may be more than one)

[] Practical Instruction;

[] PowerPoint;

[] Module;

[] Handout.

6. Have you ever used handout in the Mycology course (the topic of Antagonism between Molds)?

[] Ever

[] Never

7. Should the handout be made for learning on the course of topic "Antagonism Between Molds"?

\section{[] Need}

[] Not Need

8. Would you agree to make a handout on the "Antagonism between Molds" to help the implement in Mycology learning?

\section{[] Agree \\ [] Not Agree}

\section{RESULTS AND DISCUSSION}

The research results are presented in Table 1 below.

Table 1. Need Analysis of Handout

\begin{tabular}{ccc}
\hline Number of question & Frequency & Percent $\%$ \\
\hline 1 & 15 & $100 \%$ Ever \\
\hline 2 & 15 & $100 \%$ Present \\
\hline 3 & 15 & $100 \%$ Ever \\
\hline 4 & 15 & $100 \%$ Already Used \\
\hline 5 & 15 & $100 \%$ Practical Instruction; \\
& & $100 \%$ PowerPoint; \\
\hline 6 & 15 & $100 \%$ Never \\
\hline 7 & 15 & $100 \%$ Need \\
\hline 8 & 15 &
\end{tabular}

The result of need analysis that have been administered to the students, who have taken Mycology course, shows that $100 \%$ of respondents stated that they have practical activity about Antagonism between Molds and $100 \%$ of respondents stated that they have used learning materials as practical instruction and power point. $100 \%$ of respondents stated that they had never used handouts in the subject matter of the topic of Antagonism Between Molds, then 100\% of respondents stated that it is necessary to create a handout that will be used in learning the topic of "Antagonism Between Molds". $100 \%$ of respondents agreed to create a handout on the topic of "Antagonism between Molds" to help the implementation of mycology course.

In addition, the results explain that all respondents stated that they need learning material in the form of handout on the topic of "Antagonism Between Molds". Handout are learning material that are sourced from several literatures relevant to basic competencies and subject matter taught to students [8]. This instructional material is given to learners to facilitate them while following the learning process. Handout can include explanations of a material, clarify links between topics, give questions and activities to readers, and can also provide feedback and follow-up steps [5]. Based on the conditions described from the questionnaire survey needs analysis, the learning material in the form of handout required by the students in understanding and learning to be more detailed about the topic "Antagonism Between Molds" in the mycology course.

\section{CONCLUSION}

Based on the results of research need analysis has been done, it can be concluded that the learning material in the form of handouts required by students in understanding and studying to be more detailed about the topic "Antagonism Between Molds" in the mycology course.

\section{ACKNOWLEDGMENT}

The authors would like to thank the students class of 2014 Biology Department, State University of Malang as respondents in this research.

\section{REFERENCES}

[1] Majid, A., Perencanaan Pembelajaran. Bandung: PT Remaja Rosda Karya, 2007.

[2] Bilesanmi, A. J. B. \& Idowu O. D., "Effectiveness of Cooperative Learning Strategies on Nigerian Junior Secondary Students' Academic Achievement in Basic Science," British Journal of Education, Society \& Behavioural Science, vol. 2(3), pp. 307-325, 2012.

[3] Farnaz, Z. A. and Jarahi L., "Distribution of Handouts in Undergraduate Class to Create More Effective Educational Environment," International Journal of Education and Research, vol. 1(12), pp. 78-87, 2013.

[4] Islam, M. N. and Majumder, A. A., "Students' Perceptions of Technology-Based' Lecture Handouts," Malaysian Journal of Medical Sciences, vol. 12(1), pp. 26-28, 2005.

[5] Kinchin, I., "Developing PowerPoint Handouts to Support Meaningful Learning," British Journal of Educational Technology, vol. 37(4), pp. 647-650, 2006.

[6] Noppe. I. C., "PowerPoint Presentation Handouts and College Student Learning Outcomes," International Journal for the Scholarship of Teaching and Learning, vol. 1(1), pp. 1-13, 2007.

[7] Prastowo, A., Panduan Kreatif Membuat Bahan Ajar Inovatif: Menciptakan Metode pembelajaran yang Menarik dan Menyenangkan, Yogjakarta: Diva Press, 2011.

[8] Setiawan, D., Pengembangan Bahan Ajar. Jakarta: Universitas Terbuka, 2009. 